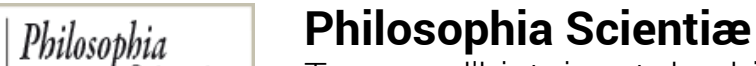

Scientia

Travaux d'histoire et de philosophie des sciences

8-1| 2004

Le problème de l'incommensurabilité, un demi-siècle après

\title{
Selective Bibliography
}

\section{(2) OpenEdition}

Journals

Electronic version

URL: http://journals.openedition.org/philosophiascientiae/606

DOI: 10.4000/philosophiascientiae.606

ISSN: $1775-4283$

Publisher

Éditions Kimé

\section{Printed version}

Date of publication: 1 May 2004

Number of pages: 269-287

ISBN: 2-84174-338-1

ISSN: $1281-2463$

Electronic reference

"Selective Bibliography", Philosophia Scientiæ [Online], 8-1 | 2004, Online since 24 June 2011,

connection on 17 January 2021. URL: http://journals.openedition.org/philosophiascientiae/606 ; DOI: https://doi.org/10.4000/philosophiascientiae.606 


\section{Selective Bibliography}

Achinstein Peter

1964 On the Meaning of Scientific Terms, Journal of Philosophy, 61: 497-509.

ACKermann RoberT

1985 Data, Instruments, and Theory: A Dialectical Approach to Understanding Science, Princeton University Press.

AgAzzi E. (EDITOR)

1997 Realism and Quantum Physics, Amsterdam-Atlanta, Ga: Rodopi. AнN W. K.

1998 Why are different features central for natural kinds and artifacts?: the role of causal status in determining feature centrality, Cognition, 69: 135-178.

Allén S. (EDITOR)

1989 Possible Worlds in Humanities, Arts and Sciences: Proceedings of Nobel Symposium 65, Berlin: Walter de Gruyter.

\section{Andersen Hanne}

1996 Categorization, Anomalies and the Discovery of Nuclear Fission, Studies in the History and Philosophy of Modern Physics, 27 (4): 463-492.

2000 Kuhn's account of family resemblance: A solution to the problem of wide-open texture, Erkenntnis, 52: 313-337.

2001 Reference and Resemblance, Philosophy of Science, 68: 50-61.

2002 The Development of Scientific Taxonomies, in [Magnani \& Nersessian 2002, 95-112].

Forthcoming Unexpected discoveries, graded structures, and the difference between acceptance and neglect, in [Nickles \& Meheus, forthcoming].

Anderson A. R., Barcan-Marcus R. and Martin R. M. (ediTORS)

1975 The logical enterprise, Yale: Yale University Press.

Andersen H., Barker P. And Chen X.

1996 Kuhn's mature philosophy of science and cognitive psychology, in Philosophical Psychology, 9: 347-363.

Andersen H. and Nersessian N.

2000 Nomic Concepts, Frame, and Conceptual Change, Philosophy of Science, 67: 224-241. 
Asquit P. And Nickles T. (EDitors)

1983 PSA 1982 (Proceedings of the 1982 Biennial Meeting of the Philosophy of Science Association), 2, East Lansing, MI: Philosophy of Science Association.

1984 PSA 1984 (Proceedings of the 1984 Biennial Meeting of the Philosophy of Science Association), East Lansing: Philosophy of Science Association.

Baltas Aristides

1988 On the Structure of Physics as a Science, in [Batens \& van Bendegem 1988, 207-226].

1990 Once Again on the Meaning of Physical Concepts, in [Nicolacopoulos 1990, 293-314].

1997 Constraints and Resistance: Stating a Case for Negative Realism, in [Agazzi 1997, 74-96].

2000 Classifying Scientific Controversies, in [Machamer, Pera \& Baltas 2000, 40-49].

In progress Physics as Self-Historiography in Actu: Identity Conditions for the Discipline (draft available on request).

BARker Peter

2001 Incommensurability and Conceptual Change During the Copernican Revolution, in [Hoyningen-Huene \& Sankey 2001, 241-273].

Barker P., Chen X. And Andersen H.

2003 Kuhn on Concepts and Categorization, in [Nickles 2003, 212245].

BARSALOU L.

1992 Cognitive Psychology: An Overview for Cognitive Scientists, Hillsdale, NJ.: Erlbaum.

BARTELS A.

1995 Chains of Meaning: A Model For Concept Formation in Contemporary Physics Theories, Synthese, 105: 347-379.

Batens D. And van Bendegem J.P. (editors)

1988 Theory and Experiment, Recent Insights and New Perspectives on their Relation, Dordrecht, Holland: Reidel Publishing Co.

Bensaude-Vincent Bernadette

1993 Lavoisier, Paris : Flammarion.

Bensaude-Vincent Bernadette and Stengers Isabelle

2001 Histoire de la chimie, Paris : La découverte.

Bird Alexander

2000 Thomas Kuhn, Chesham: Acumen. 
2001 Necessarily, Salt Dissolves in Water, Analysis, 61: 267-274.

2002a On Whether Some Laws are Necessary, Analysis, 62: 257-270.

2002b Kuhn's Wrong Turning, Studies in History and Philosophy of Science, 33: 443-463.

2003 Kuhn, Nominalism, and Empiricism, Philosophy of Science, 70: 690-719.

2004 Kuhn, Naturalism, and the Positivist Legacy, Studies in History and Philosophy of Science, forthcoming.

Bitbol Michel

1996 Mécanique quantique, une introduction philosophique, Flammarion.

1998 L'aveuglante proximité du réel, Paris : Flammarion.

2002 Science as if situation mattered, Phenomenology and the Cognitive Science, 1: 181-224.

Bitbol Michel and Laugier Sandra (editors)

1997 Physique et réalité, un débat avec Bernard d'Espagnat, Editions Frontières.

BOYD R.

1979 Metaphor and theory change: What is 'metaphor' a metaphor for?, in [Ortony 1999, 481-532].

BROWN HAROLD I.

2001 Incommensurability and reality, in [Hoyningen\& Sankey 2001, 123-141].

Buchwald J. Z. (EDitor)

1995 Scientific Practice. Theories and Stories of Doing Physics, Chicago: University of Chicago Press.

Buchwald Jed and Smith George

2001 Incommensurability and the Discontinuity of Evidence, Perspectives on Science, 9(4): 463-498.

CARnap Rudolf

1963 Intellectual Autobiography, in [Schilpp 1963].

CARrier Martin

2000 Incommensurability and Empirical Comparability: The Case of the Phlogiston Theory, In [Gärdenfors 2000].

2001 Changing Laws and Schifting Concepts. On the Nature and Impact of Incommensurability, in [Hoyningen \& Sankey 2001, 6590]. 
2002 Shifting Symbolic Structures and Changing Theories: On the Non-Translatability and Empirical Comparability of Incommensurable Theories, in [Ferrari \& Stamatescu 2002, 125-148].

CARTwRIGHT, NANCY

1993 How We Relate Theory to Observation, in [Horwich 1993, 259273].

1999 The Dappled World, Cambridge: Cambridge University Press. CASSIRER ERNST

1910 Substanzbegriff und Funktionsbegriff, Berlin: Bruno Cassirer Verlag.

Chapman M. and Dixon R.A. (EDitors)

1987 Meaning and the Growth of Understanding. Wittgenstein's Significance for Developmental Psychology, Berlin: Springer 1987.

Chen Xiang

1990 Local Incommensurability and Communicability, in [Fine, Forbes \& Wessels 1991, 67-76].

1994 How Do Scientists Have Disagreements about Experiments? Incommensurability in the Use of Goal-Derived Categories, Perspectives on Science, 2: 275-301.

1997 Thomas Kuhn's Latest Notion of Incommensurability, Journal for General Philosophy of Science, 28: 257-273.

Chen Xiang, Andersen Hanne and Barker Peter

1998 Kuhn's Theory of Scientific Revolutions and Cognitive Psychology, Philosophical Psychology, 11: 5-28.

Churchland Patricia and Churchland Paul 1998 On the contrary, Cambridge, MA: MIT Press.

Cohen R. And Wartofsky M. (EDitors)

1965 Proceedings of the Boston Colloquium for the Philosophy of Science 1962-64: In Honor of Philipp Frank, Boston Studies in the Philosophy of Science, 2, New York: Humanities Press.

Collier J.

1984 Pragmatic Incommensurability, In [Asquith \& Kitcher 1984, 146-153].

Colodny R. G. (EDitor)

1965 Beyond the Edge of Certainty, Englewood Cliffs, N.J.: PrenticeHall.

1966 Mind and Cosmos. Essays in Contemporary Science and Philosophy, Pittsburgh: University of Pittsburgh Press. 
Crary A. And Read R. (EDitors)

2000 The New Wittgenstein, London and New York: Routledge.

Cushing J. T.

1998 Philosophical Concepts in Physics, Cambridge: Cambridge University Press.

Damerow P., Freudenthal G., Mclaughlin P. and Renn J. 1992 Exploring the Limits of Pre-classical Mechanics, New York: Springer-Verlag.

DARrigol Olivier

1996 The Electrodynamic Origins of Relativity Theory, Historical

Studies in the Physical and Biological Sciences, 26: 241-312.

D'EsPagnat BERNARD

2002 Traité de physique et de philosophie, Fayard, 2002.

DevitT Michael

2001 Incommensurability and the Priority of Metaphysics, in [Hoyningen \& Sankey 2001, 142-157].

Devitt Michael And Sterelny Kim

1987 Language and Reality. An introduction to the philosophy of language, Cambridge Mass: MIT Press, 1987 (first edition), 1999 (second edition).

Doppelt Gerald

1978 Kuhn's Epistemological Relativism: An Interpretation and Defence, Inquiry, 21: 33-86.

1981 Laudan's Pragmatic Alternative to Positivism and Historicism, Inquiry, 24: 253-271.

1983 Relativism and Recent Pragmatic Theories of Scientific Rationality, in [Rescher 1983, 106-142].

1988a The Philosophical Requirements for an Adequate Conception of Scientific Rationality, Philosophy of Science, 55: 104-133.

1988b Relativism and the Reticulational Model of Scientific Rationality, Synthese, 69: 225-252.

1990 The Naturalist Conception of Methodological Standards in Science: A Critique, Philosophy of Science, 57: 1-19.

2001 Incommensurablity and the Normative Foundations of Scientific Knowledge, in [Hoyningen and Sankey 2001, 159-179].

DRUDE P.

1900 The Theory of Optics, New York: Dover, 1959.

DUHEM PIERRE

1906 La théorie Physique : son objet, sa structure, Paris : Vrin, 1989. 
English translation by P. P. Wiener, 1991: The Aim and Structure of Physical Theory, Princeton: Princeton University Press.

EARMAN J.

1989 World Enough and Space-Time, Cambridge, Mass.: The MIT Press.

FAYE JAN

1991 Niels Bohr, his heritage and legacy, Dortrecht: Kluwer.

Feigl H. et Maxwell G. (Editors)

1962 Scientific Explanation, Space, and Time, Minnesota Studies in the Philosophy of Science, Volume III, Minneapolis: University of Minnesota Press,

Ferrari M. And Stamatescu I. (EDitors)

2001 Symbol and Physical Knowledge. On the Conceptual Structure of Physics, Berlin: Springer.

FEyerabend Paul

1962 Explanation, Reduction and Empiricism, in [Feigl \& Maxwell 1962, 28-97]. Reprinted in [Feyerabend 1981, 44-96].

1965a On the "Meaning" of Scientific Terms, Journal of Philosophy, 12: $266-274$.

1965b Reply to Criticism: Comments on Smart, Sellars and Putnam, in [Cohen \& Wartofsky 1965, 223-261].

1965c Problems of Empiricism, in [Colodny 1965, 145-260].

1970 Consolations for the Specialist, in [Lakatos \& Musgrave 1970, 197-230].

1972 Die Wissenschaftstheorie - eine bisher unerforschte Form des Irrsinns?, in [Feyerabend 1978, 293-338].

1975 Against Method. Outline of an Anarchistic Theory of Knowledge, London, New Left Books. French translation, 1979: Contre la méthode, Esquisse d'une théorie anarchiste de la connaissance, Seuil, 1979.

1978 Der wissenschaftstheoretische Realismus und die Autorität der Wissenschaften (Ausgewählte Schriften I), Braunschweig: Vieweg. 1981 Realism, Rationalism and Scientific Method (Philosophical Papers 1), Cambridge: Cambridge University Press, 1981.

1987a Putnam on Incommensurability, British Journal for the Philosophy of Science, 38: 75-81.

1987b Farewell to reason, London and NY: Verso.

1993 Against Method, third edition, London: Verso. 
FIELD H.

1973 Theory Change and the Indeterminacy of Reference, Journal of Philosophy, 70: 462-481.

Fine A., Forbes M. and Wessels L. (editors)

1991 PSA 1990 (Proceedings of the 1990 Biennial Meeting of the Philosophy of Science Association), 2, East Lansing, MI: Philosophy of Science Association.

Fine K.

1994 Essence and Modality, Philosophical Perspectives, 8: 1-16.

Forster Malcolm R.

2000 Hard problems in the Philosophy of science: idealisation and commensurability, in [Nola \& Sankey 2000, 231-250].

Frege Gottlob

1892 On Sense and Meaning, in [Geach \& Black 1952, 56-78].

FRENCH A. P.

1968 Special Relativity, Cambridge Mass.: MIT Press.

Galison Peter

1987 How experiments end, Chicago: The University of Chicago

Press. French translation by Bertrand Nicquevert, 2002: Ainsi s'achèvent les expériences, Paris : La découverte.

GÄRDENFORS P. AND COLL.

2000 Proceedings of the $11^{\text {th }}$ International Congress of Logic, Methodology and Philosophy of Science, Dordrecht: Kluwer.

Gavroglu K. and Goudaroulis G.

1989 Concepts out of Context(s): The Development of Low Temperature Physics 1881-1957, Dordrecht, Holland: Martinus Nijhoff Publishers.

Gavroglu K., Goudaroulis Y.and Nicolacopoulos P. (Editors) 1989 Imre Lakatos and Theories of Scientific Change, Dordrecht: Kluwer.

Geach P. AND Black M. (EDItors)

1952 Translations from the Philosophical Writings of Gottlob Frege, Oxford: Blackwell.

Ginev D. And Cohen R. (EDitors)

1997 Issues and Images in the Philosophy of Science, Dordrecht:

Kluwer Academic Publishers.

Gooding David

1992 Putting agency back into experiment, in [Pickering 1992, 65$112]$ 
Gunderson K. (EDITOR)

1975 Language, Mind and Knowledge, Minnesota Studies in the Philosophy of Science, VII, Mineapolis: University of Minnesota Press. HACKING IAN

1982 Language, Truth and Reason, in [Hollis \& Lukes 1982, 48-66]. 1983 Representing and Intervening. Introductory Topics in the Philosophy of Natural Science, Cambridge: Cambridge University Press. French translation by Bernard Ducrest, 1989: Concevoir et expérimenter, Bourgois.

1988 On the Stability of the Laboratory Sciences, Journal of Philosophy, 85: 507-514.

1992 The self-vindication of the laboratory science, in [Pickering 1992, 29-64].

1993 Working in a New World: The Taxonomic Solution, in [Horwich 1993, 275-310].

1999 The Social Construction of What?, Harvard University Press, Cambridge: Massachusetts, 1999. French translation, 2001: Entre Science et réalité. La construction sociale de quoi?, Paris : La Découverte.

2003 L'importance de la classification chez le dernier Kuhn, Archives de Philosophie, 66(3) : 389-402.

HARRIS R. (EDITOR)

2004 Rhetoric and Incommensurability. Oxford: Oxford University Press, in press.

HEIDER E. R.

1972 Universals in color naming and memory, Journal of Experimental Psychology, 93: 10-20.

Hiley D., Bohman J. And Shusterman R. (EDitors)

1991 The Interpretative Turn: Philosophy, Science, Culture, Ithaca, NY: Cornell University Press.

Hollis M. AND Lukes S. (EDitors)

1982 Rationality and Relativism, Cambridge Mass.: M.I.T. Press. HON G.

1995 Is the Identification of Experimental Error Contextually Dependent? The Case of Kaufmann's Experiment and Its Varied Reception, in [Buchwald 1995, 170-223].

Horwitch Paul (EDitor)

1993 World Changes. Thomas S. Kuhn and the Nature of Science, Cambridge MA: MIT Press. 
Hoyningen-Huene Paul

1989 Die Wissenschaftsphilosophie Thomas S. Kuhns: Rekonstruktion und Grundlagenprobleme, Braunschweig: Vieweg. English translation by A. T. Levine, 1993: Reconstructing Scientific Revolutions. Thomas S. Kuhn's Philosophy of Science, Chicago: The University of Chicago Press.

1990 Kuhn's Conception of Incommensurability, Studies in History and Philosophy of Science, 21: 481-492.

1998 On Thomas Kuhn's Philosophical Significance, Configurations, 6: 1-14.

2000 Paul Feyerabend and Thomas Kuhn, in [Preston, Munevar \& Lamb 2000, 102-114] Oxford: Oxford University Press.

2004 Three biographies: Kuhn, Feyerabend, and incommensurability, in [Harris 2004].

Hoyningen-Huene P., E. Oberheim And H. Andersen

1996 On Incommensurability, Studies in History and Philosophy of Science, 27: 131-141.

Hoyningen-Huene P. And Sankey H. (EDitors)

2001 Incommensurability and Related Matters, Dordrecht: Kluwer. Husserl EDMund

1992 Logische Untersuchungen, Hamburg: Felix Meiner Verlag. IRZIK G. AND GRÜNBERG T.

1995 Carnap and Kuhn: Arch Enemies or Close Allies, The British Journal for the Philosophy of Science, 46: 285-307.

1998 Whorfian Variations on Kantian Themes: Kuhn's Linguistic Turn, Studies in History and Philosophy of Science, 29: 207-221. JACOB PIERRE (EDITOR)

1980 De Vienne à Cambridge, Gallimard.

KEYES M E.

1999a The Prion Challenge to the 'Central Dogma' of Molecular Biology, 1965-1991. Part I: Prelude to Prions, Studies in the History and Philosophy of Biological and Biomedical Sciences, 30: 1-20.

1999b The Prion Challenge to the 'Central Dogma' of Molecular Biology, 1965-1991. Part II: The Problem with Prions, Studies in the History and Philosophy of Biological and Biomedical Sciences, 30: 181-218.

KINDI VASSO

1994 Incommensurability, Incomparability, Irrationality, Methodology and Science, 27: 40-55. 
1995 Kuhn's "The Structure of Scientific Revolutions" Revisited, Journal for General Philosophy of Science, 26: 75-92.

2004 Kuhn and Wittgenstein: Philosophical Investigations on the Structure of Scientific Revolutions, Chicago, Ill.: Chicago University Press, forthcoming.

KitCher PhiLiP

1978 Theories, Theorists and Theoretical Change, The Philosophical Review, 87: 519-547.

1983 Implications of Incommensurability, in [Asquith \& Nickles 1983, 689-703].

1993 The Advancement of Science. Science Without Legend, Objectivity Without Illusions, Oxford: Oxford University Press.

Kordig C.

1971 The Comparability of Scientific Theories, Philosophy of Science, 38: 467-485.

KRIPKE SAUL

1980 Naming and Necessity. Cambridge: Harvard University Press. KROON FRED

1985 Theoretical Terms and the Causal View of Reference, Australasian Journal of Philosophy, 63: 143-166.

1987 Causal Descriptivism, Australasian Journal of Philosophy, 65: 1-17.

Kroon Fred and Nola Robert

2001 Ramsification, reference fixing and incommensurability, in [Hoyningen \& Sankey 2001, 91-121].

KRÜGER L. ET AL. (EDITORS)

1987 The Probabilistic Revolution I: Ideas in History, Cambridge Mass.: MIT Press.

KuHN THOMAS

1961 The function of Measurement in Modern Physical Science, Isis 52: 161-193. Reprinted in [Kuhn 1977, 178-224].

1962 The Structure of Scientific Revolutions, Chicago: University of Chicago Press. French translation, 1983: La structure des révolutions scientifiques, Flammarion, 1983 (including the postface of 1969).

1970a The Structure of Scientific Revolutions, second edition, Chicago:

University of Chicago Press.

1970b Reflections on my critics, in [Lakatos \& Musgrave 1970, 231-

278]. Reprinted in [Kuhn 2000, 123-175] 
1974 Second Thoughts on Paradigms, in [Suppe 1974, 459-482]. Reprinted in [Kuhn 1977, 293-319].

1977 The Essential Tension: Selected Studies in Scientific Tradition and Change, Chicago: University of Chicago Press.

1978 Black Body Theory and the Quantum Discontinuity 1894-1912, Chicago, Ill.: The University of Chicago Press.

1979 Metaphor in science, in [Ortony 1979, 409-419]. Reprinted in [Kuhn 2000,196-207].

1983a Commensurability, Comparability, Communicability, in [Asquit \& Nickles 1983, 669-688]. Reprinted in [Kuhn 2000, 33-57].

1983b Response to Commentaries', in [Asquith \& Nickles 1983, 712716].

1984 Scientific development and lexical change, The Thalheimer Lectures, The John Hopkins University, 12 to 19 november 1984 (unpublished).

1987 What are Scientific Revolutions?, in [Krüger 1987, 7-22]. Reprinted in [Kuhn 2000, 13-32].

1989 Possible Worlds in History of Science, in [Allén 1989, 9-32]. Reprinted in [Kuhn 2000, 58-89].

1990a Dubbing and Redubbing: The Vulnerability of Rigid Designation, in [Savage 1990, 198-318].

1990b An Historians Theory of Meaning, Unpublished talk to the

Cognitive Science Colloquium, UCLA 4/26/90. Thomas S. Kuhn

Papers. (MC 240) Institute Archives and Special Collections, MIT

Libraries, Cambridge, Massachusetts.

1990c The Road since Structure, in [Fine, Forbes \& Wessels 1991, 3-13]. Reprinted in [Kuhn 2000, 90-104].

1991 The Natural and the Human Sciences, in [Hiley, Bohman \& Shusterman 1991, 17-24]. Reprinted in [Kuhn 2000, 216-223].

1992 The Trouble with the Historical Philosophy of Science, Robert and Maurine Rothschild Distinguished Lecture, 19 November 1991, Cambridge Mass., an Occasional Publication of the Department of the History of Science, Harvard University. Reprinted in [Kuhn 2000, 105-120].

1993 Afterwords, in [Horwitch 1993, 311-342]. Reprinted in [Kuhn 2000, 244-252].

2000 The Road Since Structure. Philosophical Essays, 1970-1993, with an Autobiographical Interview, edited by James Conant and John Haugeland, Chicago: Chicago University of Chicago Press. 
LADYMAN JAMES

1998 What is Structural Realism?, Studies in History and Philosophy of Science 29: 409-424.

LAKATOS IMRE

1976 Proofs and Refutations, Cambridge, U. K.: Cambridge University Press.

1978 The methodology of scientific research programmes, I, Cambridge: Cambridge University Press.

Lakatos Imre And Musgrave allan (Editors)

1970 Criticism and Growth of Knowledge: Proceedings of the International Colloquium in the Philosophy of Science, London 1965, 4, Cambridge: Cambridge University Press.

LAKOFF G.

1987 Women, fire and dangerous things: What categories reveal about the mind, Chicago: Chicago University Press.

LATOUR BRUNO,

1997 Nous n'avons jamais été modernes, Paris : La découverte.

LAUDAN LARRY

1977 Progress and its Problems. Towards a Theory of Scientific Growth, Berkeley, University of California Press. French translation, 1977: La dynamique de la science, Pierre Mardaga éditeur. 1984 Science and Values: The Aims of Science and Their Role in Scientific Debate, Berkeley CA: The University of California Press. 1987 Progress or Rationality? The prospect for Normative Naturalism, American Philosophical Quarterly, 24: 19-31. Reprinted in [Laudan 1996, 125-141].

1990 Science and Relativism. Some Key Controversies in the Philosophy of Science, Chicago: University of Chicago Press.

1996 Beyond Positivism and Relativism: Theory, Method and Evidence, Westview Press, Boulder CO.

LAUGiER SANDRA (EDITOR)

2003 T. S. Kuhn, après la Structure, thematic volume of the Archives de Philosophie, 66 (3), 2003.

LEWIS D.

1970 How to Define Theoretical Terms, Journal of Philosophy of Science, 67: 427-446.

1984 Putnam's Paradox, Australasian Journal of Philosophy of Science, 62: 221-237. 


\section{LOCKE JOHN}

1690 An Essay Concerning Human Understanding, A.D. Woozley editor, Glasgow: Collins, III, vi, 13, 1964.

Lorentz H. A.

1899 Simplified Theory of Electrical and Optical Phenomena in Moving Systems, in [Schaffner 1972, 255-273].

Machamer P., Pera M. and Baltas A. (editors)

2000 Scientific Controversies, Oxford, U.K.: The Oxford University Press.

Magnani L. and Nersessian N. (editors)

2002 Model-Based Reasoning: Science, technology, values, Dordrecht: Kluwer.

Margolis E. And Laurence S. (EDitors)

1999 Concepts: Core Readings, Cambridge, MA: MIT Press.

MCCORMMACH R.

1970 Einstein, Lorentz, and the Electron Theory, Historical Studies in the Physical Sciences, 2: 41-87.

MCDOWELL J.

1996 Mind and World, Cambridge, Mass.: Harvard University Press.

Miller A. I.

1981 Albert Einstein's Special Theory of Relativity. Emergence (1905) and Early Interpretation (1905-1911), Reading Mass.: AddisonWesley.

Moberg D.

1979 Are There Rival, Incommensurable Theories?, Philosophy of Science, 46: 244-262.

Moore T.E. (EDITOR)

1973 Cognitive development and the acquisition of language, New York: Academic Press.

Morawetz T.

1980 Wittgenstein and Knowledge, Sussex, U. K.: The Harvester Press.

Murphy G. L. And Medin D. L.

1985 The role of theories in conceptual coherence, Psychological Review, 92: 289-316. Reprinted in [Margolis \& Laurence 1999, 425$458]$.

NASIO J.-D.

1992 Cinq Leçons sur la Théorie de Jacques Lacan, Paris, France: Rivages. 
Neisser U. (EDITOR)

1987 Concepts and Conceptual Development: Ecological and Intellectual Factors in Categorization, Cambridge: Cambridge University Press.

\section{NERSESSIAN NANCY}

1982 Why is 'incommensurability' a problem?, Acta Biotheoretica, 31: 205-218.

1984 Faraday to Einstein: Constructing Meaning in Scientific Theories, Dordrecht: Kluwer.

1986 Why Wasn't Lorentz Einstein?, An Examination of the Scientific Method of H.A. Lorentz, Centaurus, 29: 205-242.

1989 Scientific Discovery and Commensurability of Meaning, in [Gavroglu, Goudaroulis \& Nicolacopoulos 1989, 323-334].

2001 Concept Formation and Commensurability, in [HoyningenHuene \& Sankey 2001, 275-301].

Nersessian N. And H. Andersen.

1997 Conceptual Change and Incommensurability: A Cognitive-Historical View, Danish Yearbook of Philosophy, 32: 111-151.

Nickles Thomas (EDitor)

2003 Thomas Kuhn, Cambridge: Cambridge University Press.

Nickles T. And Meheus J. (EDitors)

Forthcoming Proceedings of the International Congress on Discovery and Creativity, Dordrecht: Kluwer.

Nicolacopoulos P. (EDITOR)

1990 Greek Studies in the Philosophy and History of Science, Dordrecht, The Netherlands: Kluwer Academic Publishers.

Nola RoBert

1980 Fixing the Reference of Theoretical Terms, Philosophy of Science, 47: 505-531.

Nola R. et SANkey H.

2000a After Popper, Kuhn and Feyerabend, Recent Issues in Theories of Scientific Method, Kluwer Academic Publishers.

2000b A selective Survey of Theories of Scientific Method, After Popper, Kuhn and Feyerabend, in [Nola \& Sankey 2000, 1-65].

NorRIS C.

1997 Ontological relativity and meaning-variance. A critical-constructive view, Inquiry, 40: 139-173. 
ORTONY A. (EDITOR)

1979 Metaphor and Thought, Cambridge: Cambridge University Press. Second edition, 1999.

PAgondiotis K.

2004 Can the Perceptual be Conceptual and Non-Theory-Laden?, in [Raftopoulos 2004].

PAPINEAU D.

1979 Theory and Meaning, Oxford: Clarendon Press.

1996 Theory-dependent Terms, Philosophy of Science, 63: 1-20.

PARRINI PAOLO

2002 L'empirismo logico, Roma: Carocci editore.

Pera MARCEL

1994 The Discourses of Science, Chicago, Ill.: Chicago University Press.

PiCKERING ANDREW

1983 After Representation: Science Studies in The Performative Idiom, Proceedings of the Biennial Meetings of the Philosophy of Science Association, 2: 413-419.

1984 Constructing Quarks, A Sociological History of Particle Physics, Chicago: The University of Chicago Press.

1995 The Mangle of Practice. Time, Agency and Science, The University of Chicago Press, 1995.

Pickering ANdREW (EDitor)

1992 Science as practice and culture, Chicago: The University of Chicago Press.

Poulsen M.-B. J. And Andersen H.

2004 The Early History of the Protein-Only Hypothesis. Scientific change and Multidisciplinary Research, in [Seguin \& Reeves 2004], forthcoming.

Preston J., Munevar G. and D. Lamb (editors)

2000 The Worst Enemy of Science? Essays in Memory of Paul Feyerabend, Oxford: Oxford University Press.

Putnam H.

1973 Explication et référence, in [Jacob 1980, 307-330].

1975a The meaning of 'meaning', in [Gunderson 1975, 131-193]. Reprinted in [Putnam 1975b, 215-271].

1975b Mind, Language and Reality. Philosophical Papers, 2, Cambridge: Cambridge University Press. 
1981 Reason, Truth and History, Cambridge: Cambridge University Press.

2000 Rethinking Mathematical Necessity, in [Crary \& Read 2000, 218-231].

Quine W. V. O.

1960 Word and object, MIT Press, 1960. French translation by Joseph Dopp et Paul Gochet, 1977: Le mot et la chose, Flammarion.

1969 Ontological Relativity and Other Essays, New-York and London: Colombia University Press. French translation by Jean Largeault, 1977: Relativité de l'ontologie et autres essais, Aubier.

1987 Indeterminacy of Translation Again, Philosophy of Science, 84: $5-10$.

Raftopoulos A. (EDITOR)

2004 Cognitive Penetrability of Perception: an Interdisciplinary Approach, New York: Nova Scotia Publishing Co, Forthcoming.

RASMUSSEN S.

1987 Sense, Reference, and Meaning Incommensurability, Analysis, 47: 170-173.

READ RUPERT

2003 Kuhn: le Wittgenstein des sciences?, in [Laugier 2003, 464479],

Read Rupert ANd SHarrock Wes

2002a Kuhn, Philosopher of Scientific Revolutions, Cambridge: Polity Press/Blackwell Publishing Company.

2002b Thomas Kuhn's Misunderstood Relation to Kripke-Putnam

Essentialism, Journal for the General Philosophy of Science, 33: 151-158.

RESCHER NicOlas (EDITOR)

1983 Scientific Explanation and Understanding: Essays on Reasoning in Science, Pittsburgh: University Press of America.

Rosch E.

1973a Natural categories, Cognitive Psychology, 4: 328-350.

$1973 \mathrm{~b}$ On the internal structure of perceptual and semantic categories, in [Moore 1973, 111-144].

1987 Wittgenstein and Categorization Research in Cognitive Psychology, in [Chapman \& Dixon 1987, 151-166]. 
Rosch E. And Mervis C. B.

1975 Family Resemblance: Studies in the Internal Structure of Categories, Cognitive Psychology, 7: 573-605.

Rosch E., Mervis C. B., Gray W. D., Johnson D. M., And Boyes-BraEm P.

1976 Basic Objects in Natural Categories, Cognitive Psychology, 8: 382-439.

\section{SANKEY HOWARD}

1990 In Defence of Untranslatability, Australasian Journal of Philosophy, 68: 1-21.

1991a Incommensurability and the Indeterminacy of Translation, Australasian Journal of Philosophy, 69: 219-223.

1991b Translation Failure Between Theories, Studies in History and Philosophy of Science, 22: 223-236.

1991c Incommensurability, Translation and Understanding, Philosophical Quarterly, 41: 414-426.

1991d Feyerabend and the Description Theory of Reference, Journal of Philosophical Research, 16: 223-232.

1992 Translation and Languagehood, Philosophia, 21: 335-337.

1993 Kuhn's Changing Concept of Incommensurability, British Journal for the Philosophy of Science, 44: 759-774.

1994a The Incommensurability Thesis, Aldershot: Avebury.

1994b Judgement and Rational Theory-Choice, Methodology and Science, 27: 167-182.

1995 The Problem of Rational Theory-Choice, Epistemologia, 18: 299-312.

1996a Normative Naturalism and the Challenge of Relativism: Laudan versus Worrall on the Justification of Methodological Principles, International Studies in the Philosophy of Science, 10: 37-51. 1996b Rationality, Relativism and Methodological Pluralism, Explorations in Knowledge, 134: 18-36.

1997a Rationality, Relativism and Incommensurability, Aldershot: Ashgate.

1997b Incommensurability: The Current State of Play, Theoria, 12: 425-445.

1997c Kuhn's Ontological Relativism, in [Ginev \& Cohen 1997, 305329]. Reprinted in 2000, in Science \& Education, 9: 59-75.

1998 Taxonomic Incommensurability, International Studies in Philosophy of Science, 12: 7-16. 
Savage W. C. (EDITOR)

1990 Scientific Theories, Minnesota Studies in the Philosophy of Science, 14, Minneapolis: University of Minnesota Press.

SCHAFFNER K.

1972 Nineteenth-Century Aether Theories, Oxford: Pergamon Press.

1974 Einstein versus Lorentz: Research Programmes and the Logic of Comparative Theory Evaluation, The British Journal for the Philosophy of Science, 25: 45-78.

Schilpp P. A. (EDITOR)

1963 The Philosophy of Rudolf Carnap, Lasalle, IL: Open Court.

SEARLE John

1983 Intentionality, Cambridge: Cambridge University Press.

Seguin E. and Reeves C. (EDitors)

2004 Infectious Processes. Knowledge, Discourse, and Politics of Prions, Palgrave: Macmillan.

SHAPERE D.

1964 Review of The Structure of Scientific Revolutions by T. S. Kuhn, The Philosophical Review, 73: 383-394. French translation, 1980: La structure des révolutions scientifiques, in [Jacob 1980, 293-306].

1966 Meaning and Scientific Change, in [Colodny 1966, 41-85].

1984 Reason and the Search for Knowledge. Investigations in the Philosophy of Science, Dordrecht: Reidel.

1989 Evolution and Continuity in Scientific Change, Philosophy of Science, 56: 419-437.

2001 Reasons and Radical Change, in [Hoyningen-Huene \& Sankey 2001, 181-206].

SIEGEL H.

1980 Objectivity, Rationality, Incommensurability, and More, Review of The Essential Tension by T.S. Kuhn, British Journal for the Philosophy of Science, 31: 359-384.

1987 Relativism Refuted. A Critique of Contemporary Epistemological Relativism, Dordrecht: Reidel.

1992 Justification by Balance, Philosophy and Phenological Research, 52: $27-46$.

1998 Naturalism and Normativity: Hooker's Ragged Reconciliation, Studies in History and Philosophy of Science, 29A: 623-637. 
Soler LÉNA

1997 L'émergence d'un nouvel objet symbolique : le photon, Thèse de Doctorat de l'université Paris I.

2000a Introduction à l'épistémologie, Ellipses, 2000.

2000b Le concept kuhnien d'incommensurabilité, reconsidéré a la lumière d'une théorie structurale de la signification, Philosophia scientae, Kimé, 4(2), 2000 : 189-217.

2003 De la commune mesure phénoménale des théories physiques dites incommensurables, Philosophia Scientiae, 7(2), 2003.

2004a Etablir des correspondances entre théories physiques incommensurables, Revue Philosophique de Louvain, 3, 2004.

2004b The Kuhnian Concept of Incommensurability in the Light of a Saussurian Framework, Malaysian Journal of Science and Technology Studies, 2004, Forthcoming.

Suppe (EDITOR)

1974 The Structure of Scientific Theories, Urbana, Ill.: University of Illinois Press.

VAN FRAASSEN BAS

1975 Platonism's pyrrhic victory, in [Anderson, Barcan-Marcus \& Martin 1975].

WEED D.

1997 Underdetermination and Incommensurability in Contemporary

Epistemology, Kennedy Institute of Ethics Journal, 7: 107-127.

WEINER J.

1990 Frege in Perspective, Ithaca, N.Y.: Cornell University Press.

Wigner Eugen

1979 Symmetries and reflections, Woodbridge: Ox Bow Press.

WitTGEnstein LUDWIG

1969 On Certainty, G. E. M. Anscombe and G. H. von Wright (editors), New York: Harper and Row Publishers.

ZHENG L.

1988 Incommensurability and Scientific Rationality, International Studies in the Philosophy of Science, 2: 227-236. 